Where are the animals?

\title{
DIALOGUE: YEAR 2010
}

Their multifarious, melifluous voices?

The rumbles and bays

barks and moos

meows and hisses

and whinneys

honks and squeaks

and songs and clicks and squawks and bellows and trumpets and neighs

and all that glorious howling?

The cries and the whispers?

We made then screan in terror, groan in agony

until the only whimper left is ours

and ours is the only scream.

Where are the animals?

Their multitudinous forms

furred and horned

cuddly and sleek'

the colore of rainbows and of old leaves

padded, cloven, flippered, clawed, fingered and webbed and hooved,

the clowns and the majegtics?

We got rid of them for fum.

the ate them.

We wore them.

We hung them on our iridescent walls made of artificial board.

We ground them up and fed then to

the ones we ate.

the ones wore.

the ones we hung on our iridescent walls made of artificial board.

Where are the animals?

Their loving wise, haunted-hunted eyes?

$$
\begin{aligned}
& \text { We bloodied then, } \\
& \text { blinded them, } \\
& \text { in-toxic-ated them } \\
& \text { and one by one } \\
& \text { we put them all out. }
\end{aligned}
$$

There are the animals?

we are lonely.

Yesterday, in the mirror of Creation

we saw only ourselves.

Today, there is only ourselves to see.

Where are the animals?

Are we left then with only our own yoices?

Not to worxyl

The screech and the grating of our machines

drown the sounds of our own whimpering.

Where are the animals?

Are alone

with our own image

staring

back

at us

from the pool in the Wildernegs?

Where are the animals?

Why aren't the species speciating?

They are there:

terror-free in un-bound repose

in the wamb of eternity.

their eyes being their own again.

they watch us

they wait

PAULETTE CALLEN

for us to finish our own destruction,

when it will be safe for then to be born once more. 